\title{
Root biomass under different soil uses and native Cerrado in Tocantins, Brazil
}

\author{
Biomassa de raízes sob diferentes usos do solo e Cerrado nativo em Tocantins, Brasil \\ Biomasa de raíces bajo diferentes usos del suelo y Cerrado nativo en Tocantins, Brasil
}

Received: 01/04/2022 | Reviewed: 01/09/2022 | Accept: 01/12/2022| Published: 01/14/2022

Dayane de Souza Lima

ORCID: https://orcid.org/0000-0001-8879-9539

Universidade Federal do Tocantins, Brazil

E-mail: daythi16@gmail.com

Laila Sirino de Araújo

ORCID: https://orcid.org/0000-0003-3894-8115

Universidade Federal do Tocantins, Brazil

E-mail: laila.sirino@mail.uft.edu.br

Moacyr Cunha Filho

ORCID: https://orcid.org/0000-0002-3466-8143

Universidade Federal Rural de Pernambuco, Brazil

E-mail: moacyr2006@gmail.com

Francisco Sandro Rodrigues Holanda

ORCID: https://orcid.org/0000-0001-6812-6679

Universidade Federal de Sergipe, Brazil

E-mail: fholanda@infonet.com.br

Alceu Pedrotti

ORCID: https://orcid.org/0000-0003-3086-8399

Universidade Federal de Sergipe, Brazil

E-mail: alceupedrotti@gmail.com

Victor Casimiro Piscoya

ORCID: https://orcid.org/0000-0003-1875-9771

Universidade Federal Rural de Pernambuco, Brazil

E-mail: victorcasimiropiscoya@gmail.com

Thaiana Brunes Feitosa

ORCID: https://orcid.org/0000-0002-7731-955X

Universidade Federal do Tocantins, Brazil

E-mail: thaianabrunes@gmail.com

Raimundo Mainar de Medeiros

ORCID: https://orcid.org/0000-0003-3455-9876

Universidade Federal Rural de Pernambuco, Brazil

E-mail: mainarmedeiros@gmail.com

Luciano Marcelo Fallé Saboya

ORCID: https://orcid.org/0000-0002-7586-6867

Universidade Federal de Campina Grande, Brazil

E-mail: 1saboya@hotmail.com

Raimundo Rodrigues Gomes Filho

ORCID: https://orcid.org/0000-0001-5242-7581

Universidade Federal de Sergipe, Brazil

E-mail: rrgomesfilho@ hotmail.com

Fabricio Souza Campos

ORCID: https://orcid.org/0000-0002-5948-472X

Universidade Federal do Tocantins, Brazil

E-mail: camposvet@gmail.com

José de Oliveira Melo Neto

ORCID: https://orcid.org/0000-0001-7451-204X

Universidade Federal do Tocantins, Brazil

E-mail: joseneto_86@hotmail.com

Milton Marques Fernandes

ORCID: https://orcid.org/0000-0002-9394-0020 Universidade Federal de Sergipe, Brazil

E-mail: miltonmf@gmail.com

Renisson Neponuceno de Araújo Filho

ORCID: https://orcid.org/0000-0002-9747-1276

Universidade Federal do Tocantins, Brazil

E-mail: renisson@mail.uft.edu.br 


\begin{abstract}
Studies on the importance of root biomass and the effects that changes in vegetation coverage cause on carbon amount and stock are scarce, especially in the cerrado biome. Taking into account the scarcity of information about root biomass estimates, this work aimed to quantify root biomass under different land uses and native cerrado in Tocantins, Brazil. The research was conducted in different land uses: agriculture, pasture, eucalyptus and control with native cerrado forest. Six trenches with dimensions of $70 \times 70 \mathrm{~cm}$ were opened and root biomass was collected at depths of $0-10,10-20,20-30,30-40$ and 40-50 cm. With the aid of a sieve, root biomass was collected and separated into fine and coarse roots. The amounts of fine and coarse root biomass showed the highest mean values of 7.7 and $12.9 \mathrm{~g}$, respectively, in the eucalyptus area. Root biomass stocks were higher in the eucalyptus area, with maximum values above $3.68 \mathrm{Mg} \mathrm{ha}^{-1}$. Root biomass amounts and stocks were greater in eucalyptus areas, since forest areas, whether planted or native, manage to keep the environment in balance due to their long-term cycles, greater stability and low degree of disturbance.
\end{abstract}

Keywords: Underground biomass; Change of vegetation coverage; Root stock.

\title{
Resumo
}

Estudos sobre a importância da biomassa radicular e seus efeitos nas mudanças no uso do solo causam redução na quantidade e no estoque de carbono, principalmente no bioma Cerrado. Tendo em vista a escassez de informações sobre as estimativas de biomassas radiculares, este trabalho tem como objetivo quantificar as biomassas radiculares sob diferentes usos do solo no Cerrado em Tocantins, Brasil. A pesquisa foi realizada em diferentes usos do solo: área de agricultura, pastagem, Eucalyptus sp. e como testemunha floresta nativa de Cerrado. Seis trincheiras foram abertas com dimensões de 0,7 x 0,7 x 0,5 m, e biomassas de raízes foram coletadas em profundidades de 0-10, 10-20, 20-30, 30-40 e 40-50 cm. Com o auxílio de uma peneira, as biomassas das raízes foram coletadas e separadas em raízes finas e grossas. Os teores de biomassa de raízes finas e grossas apresentaram os maiores valores médios de 7,7 e 12,9 g kg${ }^{1}$, respectivamente, em uma área de Eucalyptus sp.. Os estoques de biomassa radicular foram maiores na área de Eucalyptus sp. com valores máximos acima de 3,68 $\mathrm{Mg} \mathrm{ha}^{-1}$. As quantidades e estoques de biomassa radicular foram maiores na área de Eucalyptus sp., uma vez que áreas florestais, sejam plantadas ou nativas, podem manter o meio ambiente em equilíbrio, devido aos seus ciclos de longa duração, maior estabilidade e baixo grau de perturbação nessas áreas.

Palavras-chave: Biomasa subterrânea; Mudança de cobertura vegetal; Estoque de raízes.

\section{Resumen}

Los estudios sobre la importancia de la biomasa radicular y sus efectos sobre los cambios en el uso del suelo provocan una reducción en la cantidad y stock de carbono, principalmente en el bioma del Cerrado. En vista de la escasez de información sobre estimaciones de biomasa de raíces, este trabajo tiene como objetivo cuantificar la biomasa de raíces bajo diferentes usos de la tierra en el Cerrado en Tocantins, Brasil. La investigación se llevó a cabo en diferentes usos del suelo: área agrícola, pasto, Eucalyptus sp. y como testimonio del bosque nativo del Cerrado. Se abrieron seis zanjas con dimensiones de 0,7 × 0,7 x 0,5 my se recolectaron biomasas de raíces a profundidades de 0-10, 10-20, 2030, 30-40 y 40-50 cm. Con la ayuda de un tamiz, se recogió la biomasa radicular y se separó en raíces finas y gruesas. Los contenidos de biomasa de raíces finas y gruesas tuvieron los valores medios más altos de 7.7 y $12.9 \mathrm{~g} \mathrm{~kg}^{-1}$, respectivamente, en un área de Eucalyptus sp. Las existencias de biomasa de raíces fueron mayores en el área de Eucalyptus sp. con valores máximos superiores a 3,68 $\mathrm{Mg} \mathrm{ha}^{-1}$. Las cantidades y existencias de biomasa radicular fueron mayores en el área de Eucalyptus sp., Ya que las áreas forestales, ya sean plantadas o nativas, pueden mantener en equilibrio el medio ambiente, debido a sus ciclos de largo plazo, mayor estabilidad y bajo grado de perturbación en estas áreas.

Palabras clave: Biomasa subterránea; Cambio de cobertura vegetal; Stock de raíz.

\section{Introduction}

Plants have the ability to produce their own food through the photosynthesis process, and as a result, it generates biomass (Vinhal-Freitas et al., 2017). This process assimilates CO2 from the atmosphere and stores carbon in the biomass, and with that, studies on biomass production and storage of greenhouse gases, particularly carbon dioxide, have been developed (Soleimani et al., 2019).

Human activities have caused an increase in the concentration of greenhouse gases (GHG) in the atmosphere, mainly due to interference in land use, which consequently influences the capacity of soils to store CO2 present in plant biomass (Le Quéré et al., 2018; Santana et al., 2020).

Non-anthropized forest coverages provide greater carbon stocks in the soil due to the high deposition of nutrients, 
organic matter, since management, disturbance intensity, land use changes and successional stages are factors that influence biomass volume and carbon reserves that are deposited in the soil over time (Primieri et al., 2017).

Studies on estimates of aboveground carbon stocks have been carried out on a global scale, which showed that the largest stocks (>200 Gt C) are found in woody plants (Freitas et al., 2017; Villarino et al., 2018; Marengo et al., 2018).

On the other hand, studies on root biomass are scarce, especially in the cerrado biome, as the heterogeneity of plant species, soil and environment in these areas impairs collection and standardization of methods for data assessment (Narvarez et al., 2017).

Land use changes can lead to changes in natural properties causing loss of nutrients and organic matter; however, the use of vegetation coverage appropriate to the region can provide less soil degradation and greater environmental sustainability (Toniello, 2019) (Feitosa et al., 2016).

Root biomass quantification regarding land use and change is still little explored, which can be observed through the reduced amount of studies (Marinho-Junioret et al., 2020). Taking into account the importance of root biomass in carbon storage and the lack of information, this work aimed to quantify root biomass under different land uses and native cerrado in Tocantins, Brazil.

\section{Methodology}

This work was conducted at the experimental farm of the Federal University of Tocantins, municipality of Gurupi, state of Tocantins, at geographical coordinates $11^{\circ} 46^{\prime} 25^{\prime \prime} \mathrm{S}$ and $49^{\circ} 02^{\prime} 54^{\prime \prime} \mathrm{W}$ (Figure 1).

Figure 1. Location of experimental areas with native forest, Eucalyptus sp., pasture and agriculture in Gurupi, Tocantins, Brazil.

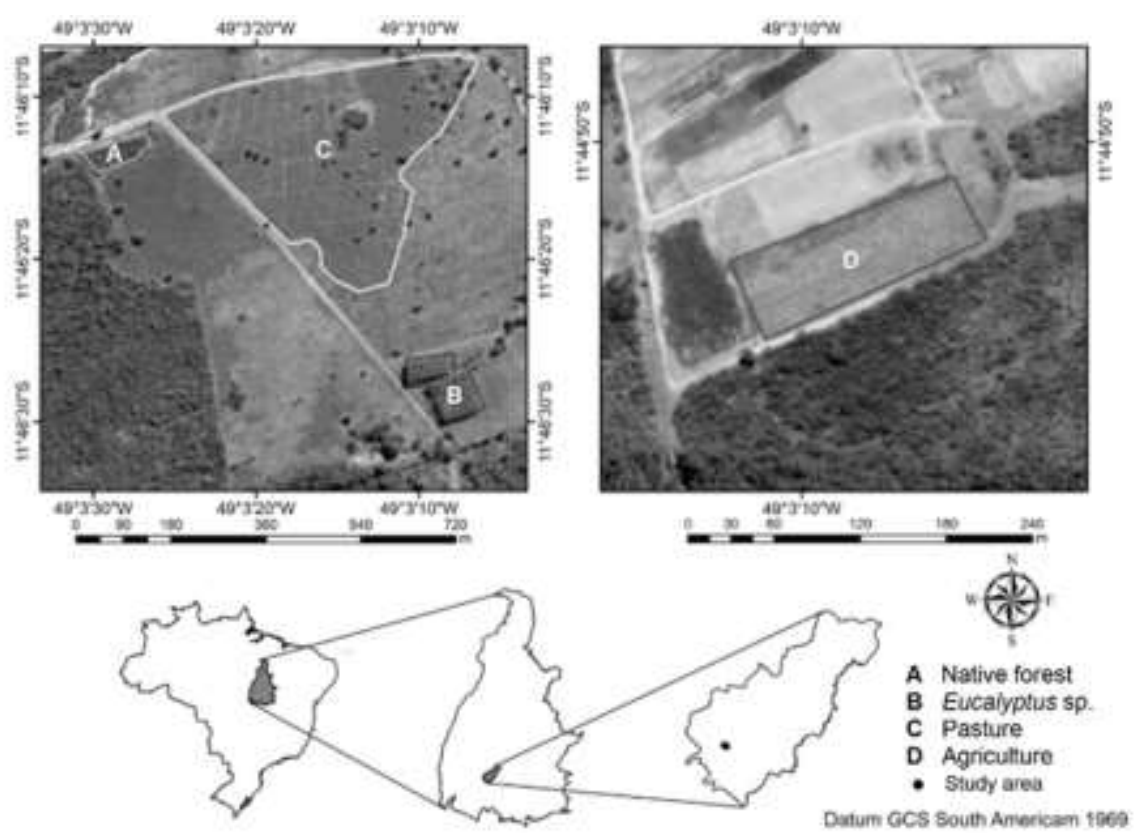

Source: Marinho-Junior et al., (2021).

According to Thornthwaite, the climate of the region is B1wA'a' type, having two well-defined seasons, with about six months of drought, comprising the winter period and six months of rain that correspond to the summer period. The average annual temperature is $27^{\circ} \mathrm{C}$ and the average annual precipitation is $1,500 \mathrm{~mm}$ (Tocantins, 2017). The soil was classified as petric Plinthosol (Santos et al., 2018). The study areas were occupied with Eucalyptus sp., Pasture, Agriculture and Native 
Forest as control. Each area had the following characteristics:

Native forest: the area aged over 60 years covers $22.82 \mathrm{ha}$, without recent vegetation burns or cuts with the following species: Myrcia splendens (Sw.) DC. (13.04\%), Qualea multiflora Mart. (9.87\%), Protium heptaphyllum (Aubl.) Marchand (7.53\%), Magonia pubescens A.St.-Hil. (5.35\%), Qualea grandiflora Mart. (5.02\%) (Bertazzini et al, 2018).

Eucalyptus sp.: the area aged 11 years covers 0.65 ha and its implementation was carried out through deforestation with bulldozer and front shovel, followed by plowing and harrowing. Seedlings of $25 \mathrm{~cm}$ in height were planted in pits of dimensions of $0.4 \times 0.4 \times 0.4 \mathrm{~m}$ with the help of excavators and $3 \times 2 \mathrm{~m}$ spacing. Fertilization was carried out with $100 \mathrm{~g}$ of simple superphosphate at the bottom of the pit and partially buried, then $150 \mathrm{~g}$ per pit-1 of NPK were added in the 5-25-15 formulation. After implementation, thinning was not carried out on trees and ground cover was composed of leaves and small Eucalyptus sp. branches. Manual weeding was also carried out in the area to control weeds.

Pasture: the area covers 11.25 ha with native pasture and predominance of Andropogon grass aged over 40 years, without the presence of animals. Other poaceas species such as Spalum notatum, Eragrostis bahiensis, Axonopus affinis, Bothriochloa laguroides, Schizachyrium microstachyum, Paspalum dilatatum, Sporobolus indicus, Rhynchospora sp., Andropogon ternatus, Panpalumis sp. have been recorded.

Agriculture: The area covers 0.95 ha and soil preparation was performed using leveling harrow and disc plow, and weeds were controlled by manual weeding associated with the use of full-action herbicides such as Glyphosate, operations adopted when necessary. Over the past 6 years, corn was grown in the area, annually planted in the period between February and March with average spacing of $0.2 \times 0.8 \mathrm{~m}$. For sowing, manual planter-fertilizer was used, which enabled basic fertilization. The nutrients applied at the time of corn sowing consists of nitrogen in the form of ammonium sulphate (45\% $\mathrm{N})$, phosphorus in the form of triple superphosphate (42\% P2O5) and potassium in the form of potassium chloride (58\% of $\mathrm{K} 2 \mathrm{O}$ ), corresponding to 120,170 and $140 \mathrm{~kg}$ ha-1, respectively of $\mathrm{N}, \mathrm{P}$ and $\mathrm{K}$, with $\mathrm{N}$ applied $50 \%$ at 25 days and $50 \%$ at 45 days after sowing. At other times of the year, no cultivation of any kind was carried out in the area, with corn stubble being the only soil coverage.

Roots were collected in six trenches with dimensions of 0.7 x $0.7 \mathrm{~m}$, at depths of 0-10, 10-20, 20-30, 30-40 and 40-50 $\mathrm{cm}$, in each study area. The soil of each layer was passed through a $4 \mathrm{~mm}$ mesh sieve, and all retained underground biomass was manually collected. Collected roots were stored in identified plastic bags and sprinkled with $70 \%$ alcohol to inhibit microbial activity. Roots were separated into two diameter classes, fine roots $\leq 5 \mathrm{~mm}$ and coarse roots $>5 \mathrm{~mm}$, with the aid of a caliper. Roots were not distinguished between dead and alive, nor separated by species. The collected root biomass was placed in paper containers and dried in a forced circulation oven at $65^{\circ} \mathrm{C}$ until reaching constant weight. Subsequently, samples were weighed to obtain the dry mass of plant components.

Root biomass stocks were calculated in $\mathrm{Mg} \mathrm{ha}^{-1}$ for each depth sampled as follows (Barbosa et al, 2012):

$$
\mathrm{ESTBR}=\mathrm{BR} \times \mathrm{Ds} \times \mathrm{VPA}
$$

Where ESTBR is the root biomass stock in the soil layer, in $\mathrm{Mg} \mathrm{ha}^{-1}$; $\mathrm{BR}$ is the root biomass concentration, in $\mathrm{kg} \mathrm{Mg}^{-}$ '; Ds is the soil density in the layer, in Mg m-3 and VPA is the volume of the sampled depth, in m3.

Data were submitted to Shapiro and Wilk normality tests and then analysis of variance (ANOVA) was performed to evaluate differences between vegetative coverages at soil depths of 0-10, 10-20, 20-30, 30-40 and 40-50 cm, with application of the $\mathrm{F}$ test. Comparison of means was performed using the Tukey test at 5\% significance and the SISVAR statistical software (Ferreira, 2011). 


\section{Results and Discussion}

Fine root amount showed the highest average values, between vegetation coverage and surface layers in all land uses, and in Eucalyptus sp., greater amounts were observed, ranging from 2.66 to $15.56 \mathrm{~g}$, in comparison with the other areas under study, except for native forest considered as control (Figure 2).

Figure 2. Amount of fine roots as a function of different land uses and depths in Gurupi, Tocantins, Brazil.

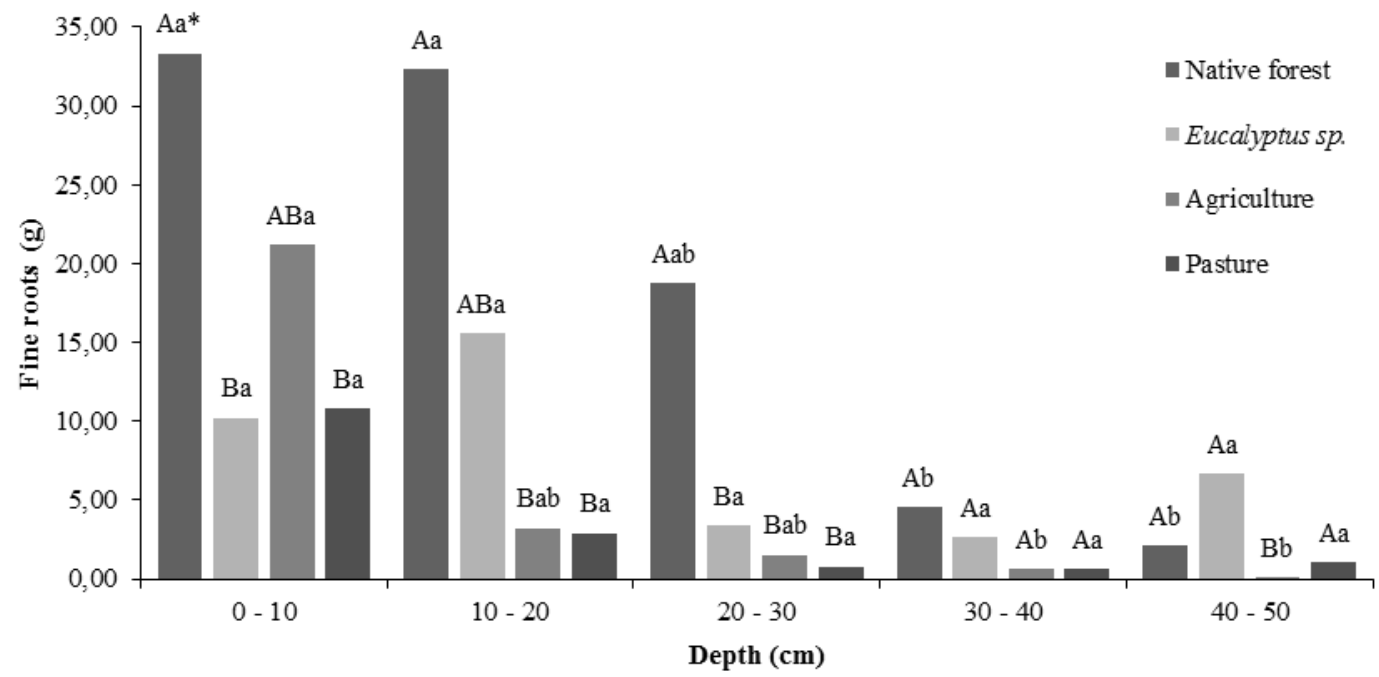

*Significant differences are indicated by different letters by the Tukey test at $5 \%$ significance $(\mathrm{P} \leq 0.05)$. Uppercase letters indicate differences between vegetation coverages and lowercase letters indicate differences between soil depths. Source: Authors (2021).

In areas where land use changes were observed, in area of Eucalyptus sp., the highest values may be linked to greater conservation of organic material, since the forest area has greater soil and root biomass protection from degrading agents when compared to areas without vegetation coverage, or in state of degradation (Nascimento et al., 2019). In a survey of fine root biomass and organic matter constituents in different areas, Barbosa et al. (2017) found values of fine roots not exceeding 3.96 $\mathrm{g}$ in eucalyptus area. In another work on the dynamics of fine roots in different areas, Mendes et al., (2018) found values around $11.00 \mathrm{~g}$, similar to those found in this work.

Another point to be highlighted is that in the layer of $0-10$, the agriculture area presented values of fine roots significantly higher than the other areas where change in vegetation coverage was observed, exceeding 20 g. These higher values of fine roots in the first layer in the agriculture area can be explained by the type of corn root system, as corn is monocotyledonous, its roots are thinner, with uniform thickness, receiving the name of fasciculate root system, which are located more superficially on the soil (Assefa et al., 2017).

The distribution of nutrients on the surface, as is the case in the agriculture area, where fertilizers were applied, leads to greater concentration of roots at this depth (Roquette, 2018).

In work on fine root dynamics in different land uses, Rosa (2018) showed that more than 50\% of fine roots were concentrated mainly in the superficial layer $(0-10 \mathrm{~cm})$, and in the agriculture area, the first layer presented approximately 0.5 $\mathrm{Mg} \mathrm{ha}^{-1}$ of stored fine roots.

The smallest amounts of fine roots were found in the pasture area, and as the depth increased, the mean values of fine roots decreased Figure 2. These lower values can be explained by the degree of degradation in the area, as with the reduction of vegetation coverage, the amounts of roots also decreased (Premrov et al., 2017). According to Andrade et al., (2020), the amount of fine roots in pasture area ranged from 5.33 to $25.83 \mathrm{~g}$, which are within values found in this study. The same authors 
also reported that the results found in their work in relation to the behavior of fine root biomass are inversely proportional to depth, and the amounts of roots decreased around $36 \%$ in the layer of $5-30 \mathrm{~cm}$.

The significant mean values of coarse roots were higher in Eucalyptus sp. with values ranging from 9.77 to $16.04 \mathrm{~g}$ in the superficial layers of 0-10 and 10-20 cm, except for native forest considered as control Figure 3.

Figure 3. Amount of coarse roots as a function of different land uses and depths in Gurupi, Tocantins, Brazil.

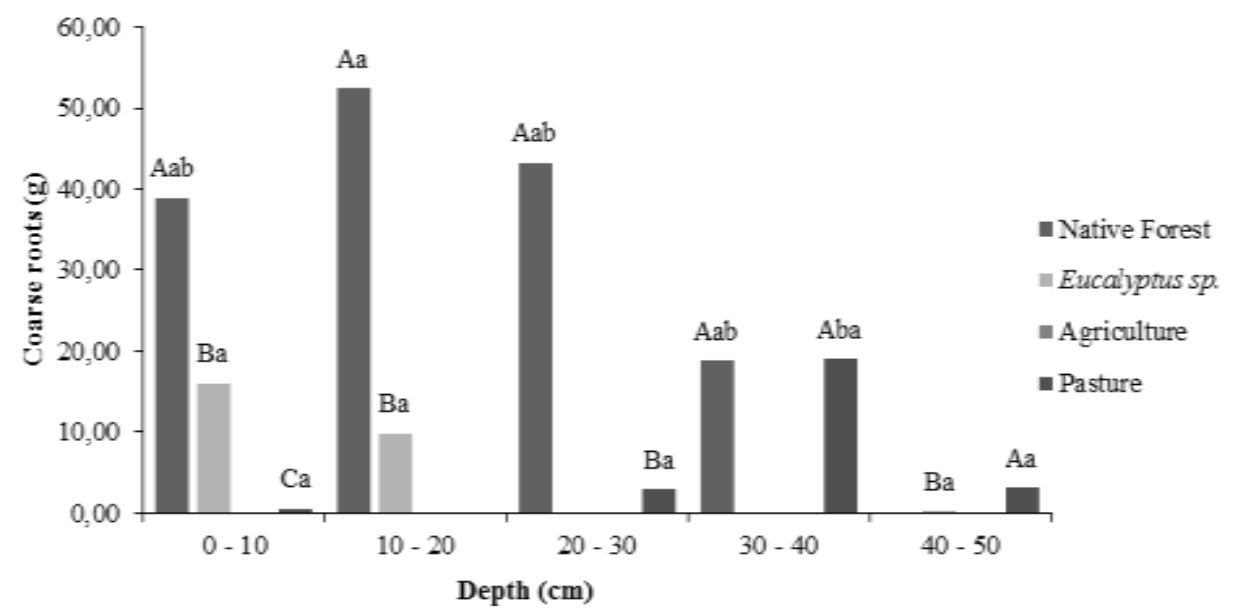

*Significant differences are indicated by different letters by the Tukey test at $5 \%$ significance $(\mathrm{P} \leq 0.05)$. Uppercase letters indicate differences between vegetation coverages and lowercase letters indicate differences between soil depths. Source: Authors (2021).

Areas with forest monocultures such as Eucalyptus sp. tend to present high biomass increase rates, both aboveground and underground, due to its homogeneity and high degree of development (Miccolis et al., 2016). Another explanation is that the larger amounts of coarse roots in eucalyptus areas are related to the $\mathrm{C} / \mathrm{N}$ ratio of the organic material, as the higher, the longer it takes for the material to be decomposed, remaining stocked in the soil (Colatto et al., 2019).

In the work carried out by Dias et al., (2017) on the distribution and morphology of the root system, the authors found values of coarse roots in an eucalyptus area that exceed $15 \mathrm{~g}$ in the layer of 0-10, values similar to those found in this work.

In layers of 20-30 and 40-50 cm, the amount of coarse roots was significantly higher in the pasture area compared to other areas, where change in vegetation coverage was observed, with the highest value above $15 \mathrm{~g}$. These higher values of coarse roots in pasture area may be related to the deposition of weed roots over the years, accumulating in deeper layers, since the area was not submitted to weed removal (Favarin et al., 2019).

Another point that may explain this greater accumulation of coarse roots in deeper layers is the compaction in more superficial layers, due to the traffic of cattle, thus hindering the development of roots in these layers (Linhares et al., 2016). In work carried out by Rosa (2018) on vegetation coverage and biomass stock changes, the author found values of coarse root stocks in a pasture area between 12 and $13 \mathrm{~g}$ in the layer of $20-50 \mathrm{~cm}$, values below those found in this work.

In the agriculture area, the occurrence of coarse roots was not observed Figure 3. The occurrence of annual crops, usually with superficial and thin roots in agriculture areas, directly influenced the amount of coarse roots in the soil, since most annual crops have roots that are divided into seminal and nodal, where roots have approximately the same diameter, and distinguishing the main root is not possible (Assefa et al., 2017).

Root biomass stocks were significantly higher in Eucalyptus sp. in relation to the other areas, except for native forest considered as control Figure 4. 
Figure 4. Soil root biomass stocks as a function of different land uses and depths in Gurupi, Tocantins, Brazil.

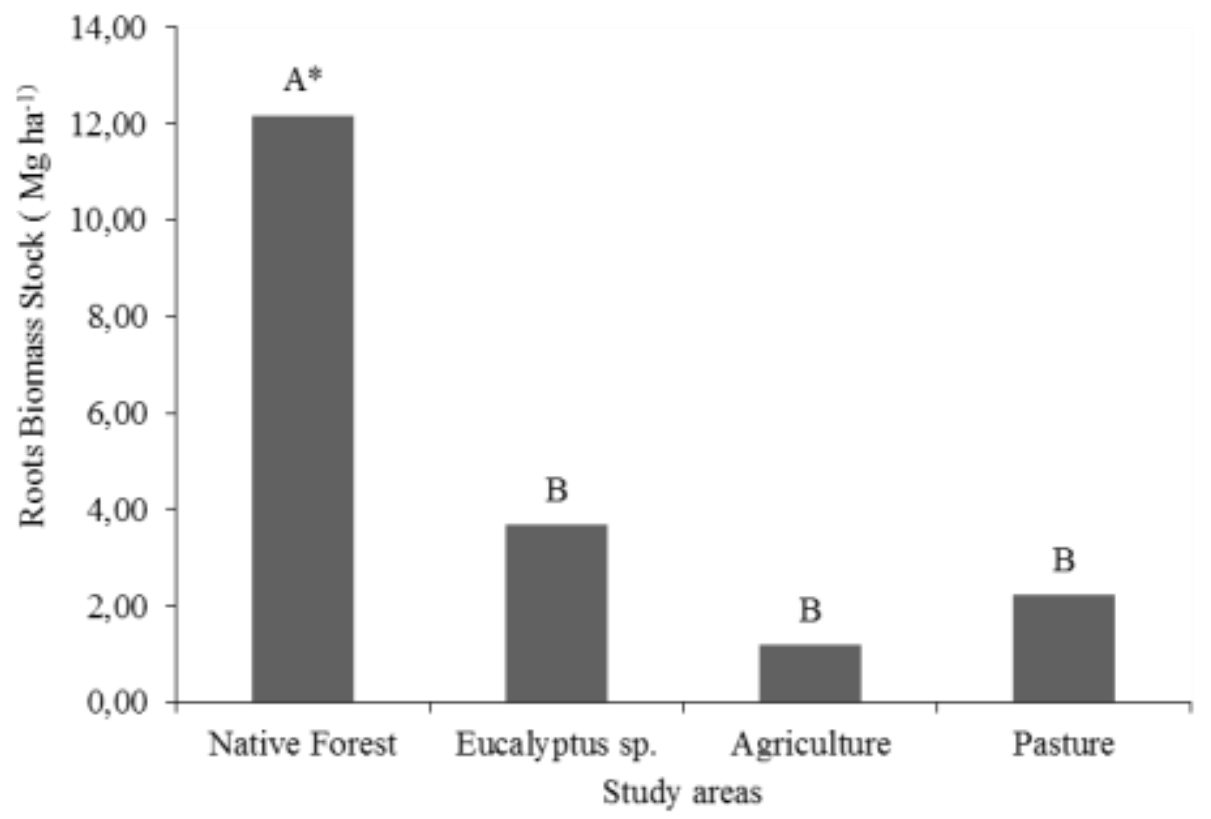

*Significant differences are indicated by different letters by the Tukey test at $5 \%$ significance $(\mathrm{P} \leq 0.05)$. Capital letters indicate differences between vegetation coverages. Source: Authors (2021).

In soil with Eucalyptus sp., this greater root biomass stock may be directly linked to the size of the forest and its ability to maintain organic matter in the soil for longer time due to its high lignin content and high $\mathrm{C} / \mathrm{N}$ ratio (Klug et al., 2020). Ribeiro et al., (2017) found root biomass stock values close to those found in this work in eucalyptus area, with average value close to $2.00 \mathrm{mg} \mathrm{ha}^{-1}$. In another work carried out by Garcia et al. (2019), the authors found in their work root biomass stock value in eucalyptus area much higher than that found in this work, $17.06 \mathrm{Mg} \mathrm{ha}^{-1}$.

On the other hand, the root biomass stock was significantly smaller in the agriculture area, not exceeding $1.18 \mathrm{Mg} \mathrm{ha}^{-}$

${ }^{1}$ (Figure 4). This lower value can be explained by the frequent soil disturbance, making the soil vulnerable due to exposure to external actions, impairing its protection from weather events, accelerating the decomposition of organic material such as, for example, roots (Salomão et al., 2019).

In work carried out by Albuquerque et al. (2016) on root biomass in areas with different land uses, the authors found values higher than those of this work in agriculture area, around $9.8 \mathrm{Mg} \mathrm{ha}^{-1}$. In another work carried out by Wolschick et al. (2016) on root stock in different vegetation coverages, the authors found values close to those found in this work in the agriculture area, ranging from 1.35 to $4.53 \mathrm{Mg} \mathrm{ha}^{-1}$.

\section{Conclusion}

Root biomass amounts and stocks in the Eucalyptus sp. area were higher in relation to other land uses such as agriculture and pasture. In general, the root biomass amount of the Eucalyptus sp. area was similar to that of native forest, since forests, whether planted or native, manage to keep the environment in balance, due to their long-term cycles, greater stability and low degree of disturbance.

Another very interesting point to be evaluated in future work is the effect of the change in land use on the amount of chemical elements present in root biomass, since they are of paramount importance in making the decision on which management to adopt. 


\section{Acknowledgments}

To the support received from the Federal University of Tocantins - UFT, Federal University of Sergipe - UFS and Federal Rural University of Pernambuco - UFRPE. Granting of scholarships by the Coordination for the Improvement of Higher Education Personnel - CAPES and the National Council for Scientific and Technological Development - CNPq.

\section{References}

Albuquerque, J. M., Watzlawick, L. F., Koheler, H. S. \& Mazon, J. A. (2016). Diferenças Fitossociológicas entre áreas de Ombrófila Mista em Sistema Faxinal no Paraná. Brazilian journal of applied Technology for agricultural science, 8(2), 63-71.

Andrade, E. M., Rosa, G.Q., Almeida, A. M. M., Silva, A. G. R. \& Sena, M. G. T. (2020). Rainfall regime on fine root growth in a seasonally dry Tropical Forest. Rev. Caatinga, 33(2), $458-469$.

Assefa, D. et al. (2017). Fine Root Dynamics in Afromontane Forest and Adjacent Land Uses in the Northwest Ethiopian Highlands. Forests, 8(7), 249.

Barbosa, V., Garcia, P. B., Rodrigues, E. G. \& Paula, A. (2017). Biomassa, Carbono e Nitrogênio na Serapilheira Acumulada de Florestas Plantadas e Nativa. Floresta e Ambiente. http://dx.doi.org/10.1590/2179-8087.024315.

Bertazzini, M., Sacchi, G. A. \& Forlani, G. (2018). A differential tolerance to mild saltstress conditions among six Italian rice genotypes does not rely on Na+exclusion fromshoots. Journal of plant physiology, 226, 145-153.

Colatto, V., Cunha, C. P., Cuba, J. A., Freita, D. J. V. \& Marostegan, P. H. C. (2019). Serviço Florestal Brasileiro Manual de campo: procedimentos para coleta de dados biofísicos e socioambientais. Serviço Florestal Brasileiro. SFB, 90.

Dias, L. P. R., Gatiboni, L. C., Brunetto, G., Arruda, B. \& Costa, M. M. (2017). Distribuição e morfologia do sistema radicular de Eucalyptus dunnii em resposta à aplicação de fósforo. Revista de Ciências Agroveterinárias, 16(3), 203-213, 10.5965/223811711632017203.

Favarin, S., Zaplana, A. S. B. \& Carneiro, E. P., L.T. L. (2019). Produção e desenvolvimento de gramínea em solo arenoso. Anais do Encontro Nacional de Ensino, Pesquisa e Extensão - ENEPE.

Feitosa, K. K. A., Júnior, J. F. V., Schaefe, C. E. G. R. M. I. L. S. \& Nascimento, P. P. R. R. (2016). Relações Solo-Vegetação em "Ilhas” Florestais e Savanas Adjacentes, no Nordeste de Roraima. 26(1). http://dx.doi.org/10.5902/1980509821098

Ferreira, D. F. (2011). Sisvar: a computer statistical analysis system. Ciência e Agrotecnologia, (UFLA), 35(6), 1039-1042, 10.1590/S141370542011000600001

Freitas, L., Oliveira, I. A., Silva, L. S., Frare, J. C. V., Filla, V. A. \& Gomes, R. P. (2017). Indicadores da qualidade química e física do solo sob diferentes sistemas de manejo. Unimar Ciências-ISSN 1415-1642, 26, (1-2), 08-25.

Garcia, M. L., Watzlawick, L. F. \& Silva, R. A. R. (2019). Florística e dinâmica da biomassa em dois sistemas de manejo na Floresta Ombrófila Mista. Sci. For., 47(124), 754-765.

Klug, I., Mafra, Á. L., Friederichs, A., Rech, C. \& Fert Neto, J. (2020). Atributos químicos do solo em plantios florestais em substituição à vegetação nativa em campos de altitude. Ci. Fl., 30(2), 279-290.

Le Quéré, C., Andrew, R. M., Friedlingstein, P., Sitch, S., Hauck, J. \& Pongratz, J. et al. (2018). Global Carbon Budget 2018. Earth System Science Data, 10. 2141-2194, 10.5194/essd-10-2141.

Linhares, J. M. S., Bastos, W. R., Junior, R. F. S. \& Oliveira, L. C. S. (2016). Variabilidade de atributos físicoquímicos e dos estoques de carbono orgânico em Argissolo Vermelho sob sistemas agrofloretais no Assentamento Umari Sul do Amazonas. Revista Geográfica Acadêmica, 10(1).

Marengo, J. A., Nobre, C. A., Chou, S. C., Tomasella, J., Sampaio, G., Alves, L. M., Obregón, G. O. \& Soares, W. R. (2018). Dangerous climate change in Brazil: a Brazil-UK analysis of climate change and deforestation impacts in the Amazon. Brazil: INPE, $56 \mathrm{p}$.

Marinho-Junior, J. L., Oliveira, M. D. D., Dias, J. L. A., Araújo-Filho, R. N., Melo Neto, J. O. \& Gonçalves, S. B. et al. (2019). Physical Attributes of Soil in Different Forest Cover in South of Tocantins. International Journal of Plant \& Soil Science, 31(2), 1-7, 10.9734/IJPSS/2019/v31i230205.

Marinho-Junior, J. L., Piscoya, V. C., Filho, M. C., Fernandes, M. M., Pedrotti, A., Piscoya, T. O. F., Filho, R. R. G., Campos, F. S., Holanda, F. S. R., Castro, J. B., Roncal, J. L. P. \& Araújo Filho, R. N. (2021). Soil microbiological activity under different vegetation coverages in the Cerrado biome of Tocantins state. Ci. Fl., Santa Maria, 31(3).

Mendes, L. S. S. \& Forti, M. C. (2018). Dinâmica de raízes finas em relação à disponibilidade sazonal de nutrientes e de diferentes níveis de deposição úmida em florestas tropicais / Lucinéia da Silva Sousa Mendes.INPE.

Miccolis, A., Peneireiro, F. M., Marques, H. R., Vieira, D. L. M., Arco-Verde, M. F., Hoffmann, M. R., Rehder, T. \& Pereira, A. V. B. (2016). Restauração Ecológica com Sistemas Agroflorestais: como conciliar conservação com produção. Brasília: Instituto Sociedade, População e Natureza - ISPN/Centro Internacional de Pesquisa Agropecuária -ICRAF.

Narvarez, P. N. R., Barbosa, R. I. \& Carvalho. L. C. S. (2017). Efeito dos parâmetros biométricos e da altitude em estimativas da biomassa de raízes grossas de árvores em florestas do ecótono norte da Amazônia brasileira. 
Nascimento, A. R., Sartori, C. J. \& Lafetá, B. O. (2019). Quantificação de biomassa e carbono em povoamentos de eucalipto. Trabalho de conclusão de curso apresentado ao Instituto Federal de Minas Gerais.

Premrov, A., Cummins, T. \& Byrne, K. A. (2017). Assessing fixed depth carbon stocks in soils with varying horizon depths and thicknesses, sampled by horizon. Catena, 150, 291-301.

Primieri, S., Muniz, A. W. \& Lisboa, H. M. (2017). Dinâmica do Carbono no Solo em Ecossistemas Nativos e Plantações Florestais em Santa Catarina. Floresta e Ambiente, 24, e 00110314.

Ribeiro, F. P. K., Bussinguer, A. P., Hodecker, B. E. R. \& Gatto, A. (2017). Conteúdo de nutrientes na serapilheira em três fisionomias do Cerrado do Distrito Federal. Pesquisa Florestal Brasileira, Brazilian Journal of Forestry Research, doi:10.4336/2017.pfb.37.92.1312.

Roquette, J. G. (2018). Distribuição da biomassa no Cerrado e a sua importância na armazenagem do carbono. Ciência Florestal, Santa Maria, 28(3), 13501363, http://dx.doi.org/10.5902/1980509833354

Rosa, G. Q. (2018). Estoque de carbono em diferentes usos da terra e dinâmica das raízes finas em floresta tropical seca. Dissertação apresentada ao Programa de PósGraduação em Engenharia Agrícola da Universidade Federal do Ceará.

Salomão, P. E. A., Kriebel, W., Santos A. A. \& Martins A. C. E. (2020). A importância do sistema de plantio direto na palha para reestruturação do solo e restauração da matéria orgânica. $9(2)$.

Santana, M. S., Giongo, V., Silva, V. C., Silva, V. C., Salviano, A. M. \& Andrade, E. M. (2020). Stoichiometric ratios in the soil of native and forage areas in a seasonally dry tropical forest. Revista Agro@mbiente On-line, 14. http://dx.doi.org/10.18227/1982-8470ragro.v14i0.6319.

Santos, H. G., Jacomine, P. K. T., Dos Anjos, L. H. C., Oliveira, V. A., Lumbreras, J. F.\& Coelho, M. R. et al. (2018). Sistema Brasileiro de Classificação de Solos. Embrapa, (5a ed.).

Secretaria De Planejamento E Orçamento (SEPLAN). Gerência De Indicadores Econômicos E SOCIAIS (GIES). 2017. Projeto de Desenvolvimento Regional Integrado e Sustentável. Zoneamento Ecológico-Econômico do Estado do Tocantins. Diagnóstico Ecológico-Econômico do Estado do Tocantins. Palmas: Seplan/GIES, I de II 522 p.

Soleimani, A., Hosseini, S. M., Massah Bavani, A. R., Jafari, M. \& Francaviglia, R. (2019). Influence of land use and land cover change on soil organic carbon and microbial activity in the forests of northern Iran. Catena, 177, 227-237, 10.1016/j.catena.2019.02.018.

Toniello, A. D. (2019). Efeito de doses de nitrogênio sobre a produção e decomposição de liteira e das frações de C do solo em pastos de Capim-Marandu.

Vilarino, S.H., Studdert, G. A. \& Loterra, P. (2018). Greennhouse gas inventories deriving soil organic carbom change factores and assessing soil depth relevence in Angentinean semiarid Choco. Catena, 169, 164-174.

Vinhal-Freitas, I. C., Corrêa, G. F., Wendling, B., Bobul'ská, L. \& Ferreira, A. S. (2017). Soil textural class plays a major role in evaluating the effects of land use on soil quality indicators. Ecological Indicators, 74, 182-190, 10.1016/j.ecolind. 2016.11.020

Wolschick, N. H., Barbosa, F. T., Bertol, L., Santos, K. F., Werner, R. S. \& Bagio, B. (2016). Cobertura do solo, produção de biomassa e acúmulo de nutrientes por plantas de cobertura. Revista de Ciências Agroveterinárias, 15(2), 134-143, 10.5965/223811711522016134. 